\title{
Comparison of Larval Fish Density between Seagrass Beds and Outside Seagrass Beds of the Southwestern Johor, Peninsular Malaysia.
}

\begin{abstract}
Temporal variation of fish larval density and composition between seagrass and outside seagrass beds of the southwestern Johor, Malaysia were investigated between October 2007 and September 2008. Fish larvae were sampled monthly by using a bongo net with $500 \mu \mathrm{m}$ mesh size and 30 min sub-surface tow. In situ environmental variables were also recorded during the sampling works. The fish larval assemblage comprised of 20 families from the seagrass beds and 16 families recorded from the outside seagrass beds station. In total, 3738 larvae (2,801 from seagrass and 937 from non-seagrass area) were collected. Total larva density was at 79 individuals per $100 \mathrm{~m} 3$ and 34 individuals per $100 \mathrm{~m} 3$ for seagrass beds and outside seagrass station respectively. Larval abundance varied significantly within monsoon and inter-monsoon seasons, with peaks in February-March and May-July. Top five families were Blenniidae, Clupeidae, Gobiidae, Sillaginidae and Terapontidae and they occurred consistently throughout the year. Larvae belonging to family Clupeidae $(47.94 \%$ in seagrass and $42.03 \%$ in outside seagrass) and Terapontidae (17\% in seagrass and $24 \%$ in outside seagrass) were the most abundant family in the study areas. The highest density of total larval fishes was recorded at the seagrass ecosystem. The spatial variations in larval density were not significantly $(p>0.05)$ different between the seagrass beds and open sea station.
\end{abstract}

Keyword: Fish larvae; Density; Seagrass; Johor; Malaysia. 